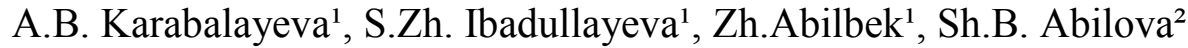 \\ ${ }^{1}$ Korkyt Ata University, Kyzylorda, Kazakhstan \\ ${ }^{2}$ Seifullin Kazakh Agrotechnical University, Nur-Sultan, Kazakhstan \\ (Corresponding author's E.mail: karabalayevaa@gmail.com) \\ ORCID ${ }^{1}$ 0000-0001-6539-2541
}

\title{
Priority issues of public health of student youth in a higher school
}

\begin{abstract}
Improving health in an educational environment allows to gain greater control over the health of students. It includes a wide range of educational and methodological activities aimed at protecting and improving the health of subjects of the educational process and improving their quality of life through the correct organization of the educational environment, and not only prevention and correction. This policy should be supported by an appropriate regulatory framework that combines the stimulation of experience and knowledge based on high-quality evidence-based information, verified health evidence, develops intellectual assets and applies ethical standards in the practice of maintaining the health of students at the university. Partnerships between public health services of the Republic of Kazakhstan and higher educational institutions are obliged to identify and share responsibility for the health of the student community and solve problems that contribute to the development of key tasks in the field of protection and preservation of public health, requiring additional efforts and mobilization of resources of the higher education system. At the republican level the functions of monitoring public health risk factors in the conditions of training students in higher education are carried out. Scientific research in the field of public health, including measures to promote healthy lifestyles, makes it possible to predict their dynamics and assess the effectiveness and quality of educational services and implementation programs for the preservation of public health. The activities of higher educational institutions in the Republic of Kazakhstan are considered from the point of view of health as the main value. A healthy student community and its well-being are based on the consolidation of efforts and available methods of preserving and developing the health of future professionals.
\end{abstract}

Keywords: educational environment, health promotion, targeted programs, educational environment, stroboscopic effect, psychological visual defect, professionalization, visualization.

\section{Introduction}

Intervention in the regulation of natural processes in the student's body does not always bring the desired positive result. Violation of at least one of the natural components of the body leads to a restructuring of the existing structure of the educational sphere of the surrounding components due to the existing interconnections between them. Reduced vision in the learning process, in turn, affects the general state of the intellectually motivating resource. It is known that the health received by nature depends only $5 \%$ on humans and $50 \%$ on environmental conditions [1]. For example, a saturated educational environment using high-speed learning technologies increases stress and requires additional effort on the part of students, which leads to an overload of the body. It is known that the visual system suffers more from these consequences.

In the process of active learning in higher education it is necessary for students to help develop a reliable and perfect natural system of protection against the dangerous effects of stress on the visual system.

The most important condition for the correct orientation of a person in the educational environment is vision, since $80 \%$ of all information a person receives is a result of a reaction to visual stimulation. The main features of the visual system are the ability to accommodate - the ability of vision to adapt to the conditions of the educational environment and the disciplines studied or in our educational process of the text of the educational material. It is known that the process of perception of visual information is limited by the visual field, the information space that learners see when the eyes and head are motionless [2].

At a viewing angle of 30-40 the viewing conditions are optimal. It is desirable that the basic information is given in this area, since it should be seen in the same way in sharp contrasts [2]. But do the teacher and the students themselves know about this?

It is known that the inertia of vision causes the stroboscopic effect. The stroboscopic effect is one of the types of optical illusions, which consists in the fusion in the consciousness of the student's personality of the subjects of study into one image of the representations of the meaning and meaning of the observed process- 
es of one's own cognition over a number of short and periodically following one after another time intervals [3].

One of the most important characteristics of the processes taking place in a living organism is their rhythm. Human vision has its limits. The disorders of the visual system in students are classified as primary somatic defects.

However, in the educational process there is a term for a psychological visual defect. The study of the mechanisms of physiological and psychological compensation was conducted by world-famous names such as I.I. Pavlov, P.K. Anochin. I.P. Pavlov, who founded the theory of compensation, the three main principles of the reflex theory: causality, the unity of analysis and synthesis, structure. P.K. Anochin showed the following:

1. The reflex character of the occurrence and course of compensatory rearrangements is based on the principles used to compensate for any deficiencies in the visual system.

2. Regardless of the type and location of the defect, compensatory corrections are made according to the same scheme and according to the same principles.

Especially significant visual impairments complicate the orientation-search activity in sensory learning. In the theory of sensory learning A.A. Wenger proved that the sensory development of students with visual impairment should occur, on the one hand, through purposeful active learning the formation of orientingsearch activity in the course of organized substantively practical actions, and on the other hand, through game technologies and exercises aimed at mastering systems of sensory standards.

Sensory development is the basis for the professional development of students-future specialists. The process of their entry into the professional field depends on how fully students learn to perceive objects, phenomena of reality in the materials of academic disciplines in order to work with this knowledge.

Sensory development implies the enrichment of sensory experience by improving the performance of all types of analyzers, especially visual ones, and therefore the mastery of the system of sensory standards by future specialists is also of great importance. At any age, sensory education has its own purpose and contributes to the sensory culture of the professional.

Sensory culture can be attributed within the framework of the theory of the formation of perceptive acts and the designation of systems of sensory qualities of an object, which are revealed in the course of sociopsychological development, and students master the methods of using them as samples when examining objects of subject study and analyzing their properties.

As such standards, language and linguistic forms of transmission of visual information can be taken into account in the higher education system. The problem of developing a professional language in future specialists with visual impairments is extremely relevant and occupies a special place in the field of higher education, as the preservation and development of the visual analyzer.

The selection of shape, size, color is an obligatory stage of the sensory perception of the world, where the development of the visual analyzer takes place. Studying these properties in an educational environment is the preservation of the visual system. The concept of the norm of the visual analyzer includes two aspects: functional (speech activity aimed at observing the norms of speech utterance and linguistic expression) and visualization (a norm as a set of visual rules established in consciousness). Visualization is a property of human consciousness, capable of reproducing visible and invisible images of the visual series in its consciousness; in fact, these are images that our consciousness perceives as a visual image or as a sensation of such a visual image [2].

The influence of thought, the role of psychological mood in maintaining human health is enormous. The visual system is a system dominated by the internal imagination. And with specific keys and approaches it is possible to learn to influence the correct functioning of the visual system, and truly inexhaustible opportunities for professional development open up for students. At the center of "working practice" at the university are always the efforts of the sector of spiritual education with the strengthening of national consciousness (a clear description of the goal, training plan, understanding of general and holistic development).

University education assumes that the development of the visualization system is the main component of imaginative thinking. It is known that eighty percent of young people perceive and process their professional experience mainly through visual images. Confidence in visual representation empowers a person to effectively explore, reproduce, and develop their own experiences, thinking, and activities. Thinking is a higher cognitive process associated with sensory perception and the visual system, and is based on visual sensations and perception of the surrounding reality [3]. 
In most cases the concept of "visualization" means creating a visual image based on an inner vision and constructing a certain image that looks like a sample. Visualization is a visual perception skill or visual sensation skill.

An unlimited amount of information from various sources for university students makes them look for a psychophysiological approach to the information and educational environment, since verbal thinking does not cope with the task [4].

\section{Experimental}

In our opinion, the main problem in the higher education system is that the visualization of the educational material of disciplines requires certain skills or competencies in the field of information and educational activities.

The increasing complexity of the content, forms and methods of general and special higher education, as well as the increased requirements for the quality of training specialists at the university, required a significant adjustment of the traditional organizational forms of the information and educational process and environmental conditions to resolve a number of contradictions:

- between the consistency of the process of professionalization of future specialists and its violation by the managerial and scientific-methodological structures of the university, which affect visual analyzers;

- between the requirements of interdisciplinary integration of content in the vocational education system as a whole and the narrow specialization of scientific and methodological support of the educational environment in terms of regulation of psychophysiological processes;

- between the need for a personal approach to professional training and the absence of a system of psychological support for any stage of professional development and the formation of a future specialist;

- between the integrity of the content of professional activity and the student's mastery of various subject areas of science, academic subjects and the development of psychophysiological competencies.

The knowledge and skills acquired in the study of the discipline "Psychophysiology" are used by students in the study of special disciplines in connection with the professional activities of individual specialists.

Students studying at the university with an appropriate modern level of knowledge in the field of natural sciences should have an idea of physiological mechanisms, relationships, mental activity in the educational environment and professional activity and develop their abilities, use this knowledge in the analysis of physiological and psychophysiological data [5]. Development of visual analyzer in the educational environment in psychology is defined as the associative relationship of unrelated events in a single system of objects and phenomena that are reflected in consciousness as a process of mental activity. In this regard, in modern conditions the concept of "innovative potential" of creative development of a future specialist at the university level of professional training is of particular importance [6].

Only a student as a creative person can successfully fulfill his professional functions, whose professional knowledge and skills do not outweigh civic responsibility, human qualities and relationships, but are synthesized with them, interpenetrating and complementing each other. Modern students are dominated by visual mechanisms that allow them to process information flows at high speed and at the same time in a more holistic manner. Visualization as a professional competence is a manifestation of figurative thinking imagination. Visualization is an ability inherent in all people, but, like many other abilities given to man by nature, if not used, it gradually atrophies which leads to a violation of the visual system.

In our study we examined three types of visualization: external, internal and visualization of sensations (Table 1).

$\mathrm{Tab} l \mathrm{e} 1$

Types of visualization: external, internal and visualization of sensations

\begin{tabular}{|c|l|l|}
\hline № & \multicolumn{1}{|c|}{ Visualization types } & \multicolumn{1}{c|}{ Description } \\
\hline 1 & External visualization & $\begin{array}{l}\text { Used in development - mental pictures are drawn, they are seen as if through } \\
\text { the eyes of an outside observer }\end{array}$ \\
\hline 2 & Internal visualization & Scrolling pictures, the participant of which is the renderer then self \\
\hline 3 & Sensation visualization & $\begin{array}{l}\text { The type of visualization is actually not important "visible" images — here, first } \\
\text { of all, sensations are important. The renderer feels everything it represents }\end{array}$ \\
\hline
\end{tabular}


The greatest effect in the assimilation of educational material is provided by a combination of internal visualization with visualization of sensations, but external visualization itself is quite effective. Visualization is not only visual representation, but also tactile, olfactory, kinesthetic, gustatory and auditory representation. And all these representations (imaginary images) depend on the development of the sense organs and the structure of visual memory.

Before a student can succeed in a future profession, he must clearly understand what he is trying to achieve. Moreover, a simple representation of the ultimate goal is clearly not enough. Visualization is one of the most effective tools for achieving the goals of a future specialist and solving problems. Such requirements for a specialist in higher education are designed to change the view on the essence of higher education, which should be based not on a simple transfer of psychological and pedagogical knowledge to students, but on the formation of skills and abilities that are not limited to the curriculum, but also the development of interdisciplinary competencies. Personal development cannot be limited to a specific period, but is carried out throughout a person's life [7].

In particular, UNESCO is helping to strengthen countries' capacities for high-quality lifelong learning, and is developing evidence-based strategies that respond to emerging trends and aim to make higher education more innovative. The higher the level of intellectual and moral development of future specialists, the faster the individual's ability to develop innovative potential and natural resource as creative selfimprovement increases [8].

Psychological and pedagogical science has developed various approaches to studying the process of professional development of a future specialist. Some researchers consider professional development from the standpoint of the motivational sphere of an individual, others - from the standpoint of the activity of this individual, and still others from the standpoint of the effectiveness of professional training of students at a university [9].

A certain novelty of our approach to the problem of professional development at the university stage is contained already in the object of analysis - the professional development of a future specialist, while the most common object is the study of the professional development of certain psycho-physiological capabilities. This is the mastery of methods of managing one's functional states when performing professional tasks on the basis of moral norms, professional ethics and official etiquette.

\section{Results and Discussion}

The development of competence to manage their functional states is one of the most pressing problems.

Visual perception of color, processing of the received visual information depends to a large extent on lighting. Therefore it is necessary to pay special attention to the formation of the light climate. With the help of the hearing organs, a person can evaluate numerous and varied pieces of auditory information. The hearing analyzer is very sensitive, always ready to receive information and allows to partially discharge the visual analyzer.

Mechanical vibrations cause auditory perception when their frequency is in the range of 16 $20,000 \mathrm{~Hz}$. When sound propagates, energy is transmitted. Energy property of sound - intensity (sound power) at any point - energy flow per unit area in a direction perpendicular to the propagation of a sound wave $\left[\mathrm{W} / \mathrm{m}^{2}\right]$.

Auditory perception is shown on a diagram by plotting the sound pressure values at which sound is felt at each frequency, is called the hearing threshold curve (Figure 1). The hearing threshold depends on the frequency of the sound, as well as on individual's age. The absolute threshold of hearing tends to decrease with age.

One of the important safety features of the auditory sensory system is its ability to recognize the location of a source of the sound without turning the head. This phenomenon is called binaural effect. 


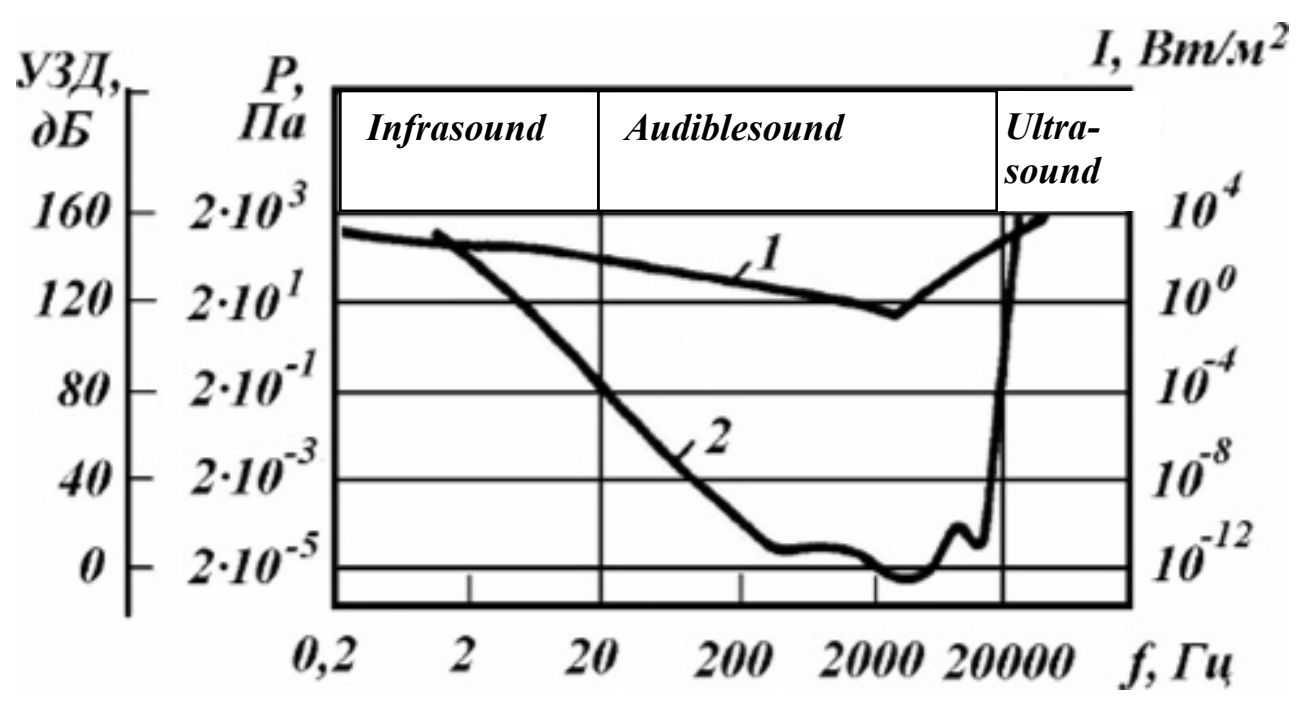

1 - upper threshold of hearing; 2 - the lower threshold of hearing

Figure 1. Diagram of the area of auditory perception

These systems ensure an adequate relative position of the limbs, as well as a stable orientation of the body in space (ensuring posture).

Static reflexes are provided by three types of receptors that perceive:

1) stretching the muscles during their relaxation - "muscle spindles";

2) muscle contraction - the Golgi tendon organs;

3) the position of the joints (causing the so-called "joint feeling").

It is assumed that their functions are performed by deep pressure receptors. The statokinetic (vestibular) system ensures the maintenance of the desired body position and the corresponding oculomotor reactions. The balance is maintained reflexively, without the participation of consciousness.

The foreign analogue of the term "management of functional psychophysiological states" is "emotional and motivational intelligence". This term was first introduced to the scientific community in 1990 by American scientists P. Salovei and J. Mayer. By this concept they understood a group of mental abilities that contribute to the awareness and understanding of the body's own natural resources [10].

Emotional-motivational intelligence is interpreted as a complex structure consisting of three types of skills: identifying and expressing emotions, regulating with the help of a visual analyzer, and using emotional information in thinking and acting. Each skill type has components.

The ability to identify and implement thinking in activities is divided into two components, including verbal and non-verbal subcomponents, and the second component includes subcomponents of non-verbal perception and empathy associated with the use of professional thinking in activities, which includes the components of flexible planning, creative thinking, distracted attention and motivation.

The professional development of the younger generation presupposes the formation and order of a number of their professionally significant and personal qualities in a certain system. By the effectiveness of the process of professional development we mean high special readiness, organically combined with the general culture and high moral qualities of the individual, the desire to achieve the highest results in creative work and constant professional improvement of the potential for innovative development [11].

Professional development as a structural and functional interaction of process components is the development of motivating needs and operatively effective areas of a specialist's personality. The needmotivational sphere as an integrative characteristic of a student's personality is determined by a number of social attitudes, value orientations and interests that underlie the motives. The operational-effective sphere of the individual, represented by a set of general and special knowledge, abilities and skills, determines the degree of mastery of modern content and technologies for solving personal and professional problems. When a student imagines the goal to be achieved, his subconscious mind is activated and begins to search for ways to achieve this goal. In the future the image of the desired is imprinted on his paper, which several times increases the chances of achieving the goal. In the process of visualization, the visual analyzer or visual system sends commands to the Higher Mind, and that, in turn, always gives the person what he asks for. 
Before starting visualization, the student must change their beliefs, which will change the course of achieving the goal. So, consider the three main steps for successful visualization (Table 2):

T a b l e 2

\section{Basic Steps for Successful Imaging}

\begin{tabular}{|c|l|l|}
\hline № & \multicolumn{1}{|c|}{ Basic steps } & \multicolumn{1}{c|}{ Goals } \\
\hline 1 & $\begin{array}{l}\text { Definition and statement of } \\
\text { purpose }\end{array}$ & $\begin{array}{l}\text { The goal must necessarily be formulated in the present tense in the first person } \\
\text { and written on paper, as if this goal has already been achieved by a person. }\end{array}$ \\
\hline 2 & $\begin{array}{l}\text { Mental presentation of the } \\
\text { result }\end{array}$ & $\begin{array}{l}\text { The goal is to supplant a person's previous negative image of reality and } \\
\text { himself, replacing it with a new, positive image }\end{array}$ \\
\hline 3 & Visual-emotional system & $\begin{array}{l}\text { The subconscious mind of a person reacts to words, as he needs feelings, } \\
\text { emotions. Moreover, the larger and brighter they are, the better. Achieving } \\
\text { success in imagination, feel all the joy of victory, satisfaction with yourself. }\end{array}$ \\
\hline
\end{tabular}

Creativity as an innovative potential for the development of the visual analyzer is a more perfect type of activity, which means that its motivating visual-emotional system is associated with internal personal needs.

The process of professional development as an innovative potential is divided into several stages, which is explained by its dynamics and multilevel character.

\section{Conclusions}

In the work on vocational training there is a clear delineation of the aspects of professionalization and the professional and psychophysiological factors that determine them, as well as a mixture of a number of conceptual categories series: vocational education and specialist training; preparation, readiness, readiness of the visual system; professional education and the formation of a future specialist.

Thus, the relevance of the topic is determined by the demand for psychophysiological analysis and research of new approaches to understanding the essence of health as a universal value based on its high significance, responsibility for preserving, substantiating the regularity of the relationship between individual health and the health of society as a single system.

\section{References}

1 Шмидт Р. Основы сенсорной физиологии: учеб. пос. / Р. Шмидт. - М.: Мир, 1984. — 287 с.

2 Шульговский В.В. Сравнительная физиология анализаторов: учеб. пос./ В.В. Шульговский, В.Г. Ерченков. - М.: Изд-во Моск. ун-та, 1989. - 123 с.

3 Александрова Т.К. Педагогика в профессиональной подготовке бакалавра и специалистов области образования / Т.К. Александрова, Т.Б.Алексеева, Е.В.Балакирева, Р.У.Богданова, Т.Г. Галактионова, А.Г. Гогоберидзеи др. - СПб.: Издво РГПУ им. А.И. Герцена, 2005. - 178 с.

4 Махмутов М.И. Проблемное обучение. Основные вопросы теории / М.И. Махмутов. — М.: Педагогика, 1975. $367 \mathrm{c}$.

5 Макеева И.В. Роль семинарского занятия в подготовке специалиста и методика управления дискуссией // Сов. педагогика / И.В. Макеева. - М.: Просвещение, 2003. — № 5. - 61 с.

6 Архангельский С.И. Учебный процесс в высшей школе, его закономерные основы и методы / С.И. Архангельский. — М.: Высш. шк., 1980. - 368 с.

7 Миронов В.А. Социальные аспекты активизации научно-исследовательской деятельности студентов вузов: моногр. / В.А. Миронов, Э.Ю. Майкова. — Тверь: ВТГТУ, 2014.

8. Кувшинова М.А. Научно-исследовательская работа студентов как важнейший фактор повышения рейтинга университета [Электронный ресурс]. — Режим доступа: http://www.research.mifp.ru/publications/npsh2.rtf

9 Сомъен Дж. Кодирование сенсорной информации / Дж. Сомъен. - М.: Мир, 1976.

10 Поляков А.Д. Самостоятельная работа студентов — творчество преподавателя / А.Д. Поляков, Г.И. Зайцев // Успехи современного естествознания. - 2008. - № 4. - С. 51-53. 


\title{
А.Б. Карабалаева, С.Ж. Ибадуллаева, Ж.Ә.Әбілбек, Ш.Б. Абилова \\ Жоғары мектеп жағдайындағы студент жастардың қоғамдық денсаулығының басты мәселелері
}

\begin{abstract}
Білім беру ортасында денсаулықты жақсарту білім алушылардың денсаулығына үлкен бақылау жасауға мүмкіндік береді. Оның құрамына тек алдын алу мен түзету емес, білім беру ортасын дұрыс ұйымдастыру арқылы білім беру процесі субъектілерінің денсаулығын қорғауға және жақсартуға және олардың өмір сүру сапасын жақсартуға бағытталған оқу-әдістемелік іс-шаралардың кең спектрі кіреді. Бұл саясатты жоғары сапалы дәлелді ақпаратқа негізделген денсаулыққа дәлелденген мәліметтер негізінде тәжірибе мен білімді ынталандыруды біріктіретін, зияткерлік құндылықтарды дамытатын және университетте студенттердің денсаулығын сақтау тәжірибесінде этикалық стандарттарды қолданатын тиісті нормативтік құқықтық базаны қолдау керек. Серіктестіктер - Қазақстан Республикасы Денсаулық сақтау қызметі және жоғары оқу орындары студенттер қауымдастығының денсаулығы үшін жыл сайынғы жауапкершілікті анықтауға және бөлуге міндетті және жоғары денсаулық сақтау жүйесінің қосымша күш-жігері мен ресурстарды жұмылдыруды талап ететін, халықтың денсаулығын сақтау саласындағы негізгі міндеттерді шешуге ықпал ететін мәселелерді шешуге міндетті. Республикалық деңгейде денсаулық сақтау қаупінің факторларын бақылау функциялары жоғары оку орындарында студенттердің білім алуы жағдайында жүзеге асырылады. Халықтың денсаулығын сақтау саласындағы ғылыми зерттеулер, оның ішінде салауатты өмір салтын насихаттау шаралары олардың динамикасын болжауға және білім беру қызметтерінің тиімділігі мен сапасын бағалауға және денсаулық сақтауды іске асыру бағдарламаларына мүмкіндік береді. Қазақстан Республикасындағы жоғары оқу орындарының қызметі денсаулық сақтау тұрғысынан басты құндылық ретінде қарастырылады. Дені сау студенттік қоғамдастық және оның әл-ауқаты болашақ мамандардың денсаулығын сақтау мен дамытудың күштері мен қол жетімді әдістерін шоғырландыруға негізделген.
\end{abstract}

Кілт сөздер: білім беру ортасы, денсаулықты нығайту, мақсатты бағдарламалар, білім беру ортасы, стробоскопиялық эффект, психологиялық визуалды ақаулар, кәсібилендіру, визуализация.

\section{А.Б. Карабалаева, С.Ж. Ибадуллаева, Ж. Алибек, Ш.Б. Абилова,}

\section{Приоритетные вопросы общественного здоровья студенческой молодежи в условиях высшей школы}

\begin{abstract}
Укрепление здоровья в условиях образовательной среды позволяет получить больший контроль над здоровьем обучающихся. Он включает в себя широкий спектр учебно-методических мероприятий, направленных на охрану и улучшение здоровья субъектов образовательного процесса и повышение качества их жизни посредством правильной организации образовательной среды, а не просто профилактики и коррекции. Эта политика должна поддерживаться надлежащей нормативно-правовой базой, которая сочетала бы в себе стимулирование опыта и знаний, основанных на качественной научно обоснованной информации, проверенных фактических данных о состоянии здоровья, развитие интеллектуальных активов и применение этических стандартов в практике сохранения здоровья обучающихся в вузе студентов. Партнерские взаимоотношения СО3 РК и высших учебных заведений обязаны ежегодно выявлять и разделять ответственность за охрану здоровья студенческого сообщества и решать проблемы, способствующие развитию ключевых задач сферы защиты и сохранения общественного здоровья и требующие приложения дополнительных усилий и мобилизации ресурсов системы высшего образования. На республиканском уровне осуществляются функции мониторинга факторов общественного здоровья риска в условиях обучения студентов в высшей школе. Научные исследования в области общественного здоровья, в том числе мероприятий по формированию здорового образа жизни, дают возможность спрогнозировать их динамику и оценить эффективность и качество образовательных услуг и программ реализации по сохранности общественного здоровья. Деятельность высших учебных заведений в РК рассмотрена с точки зрения здоровья как главная ценность. Здоровое студенческое сообщество и его благополучие базируются на консолидации усилий и доступных методах сохранения и развития здоровья будущих профессионалов.
\end{abstract}

Ключевые слова: образовательная среда, укрепление здоровья, целевые программы, образовательная среда, стробоскопический эффект, психологический дефект зрения, профессионализация, визуализация.

\section{References}

1 Shmidt, R. (1984). Osnovy sensornoi fiziologii [Fundamentals of Sensory Physiology]. Moscow: Mir [in Russian]. 
2 Shulgovskii, V.V., \& Erchenkov, V.G. (1989). Sravnitelnaia fiziologiia analizatorov [Comparative physiology of analyzers]. Moscow: Publishing house Moscow University [in Russian].

3 Alexandrova, T.K., Alexeeva, T.B., Balakireva, E.V., Bogdanova, R.U., Galaktionova, T.G., \& Gogoberidze, A.G. (2005). Pedagogika $v$ professionalnoi podgotovke bakalavra i spetsialista $v$ oblasti obrazovaniia [Pedagogy in the professional training of a bachelor and a specialist in the field of education]. Saint Petersburg: Publishing house of the Herzen RSPU [in Russian].

4 Makhmutov, M.I. (1975). Problemnoe obuchenie. Osnovnye voprosy teorii [Problematic learning. Basic questions of theor]. Moscow: Pedagogika [in Russian].

5 Makeeva, I.V. (2003). Rol seminarskogo zaniatiia v podgotovke spetsialista i metodika upravleniia diskussiei [The role of a seminar lesson in the training of a specialist and a methodology for managing a discussion]. Sovetskaiia pedagogika - Soviet pedagogy. Moscow: Prosveshchenie, 5, 61 [in Russian].

6 Arkhangelskii, S.I. (1980). Uchebnyi protsess $v$ vysshei shkole, ego zakonomernye osnovy i metody [The educational process in higher education, its natural foundations and methods]. Moscow: Vysshaiia shkola [in Russian].

7 Mironov, V.A., \& Maikova, E.Yu. (2014). Sotsialnye aspekty aktivizatsii nauchno-issledovatelskoi deiatelnosti studentov vuzov [Social aspects of enhancing the research activities of university students]. Tver: Izdatelstvo Tverskoho gosudarstvennogo universiteta [in Russian].

8 Kuvshinova, M.A. (2013). Nauchno-issledovatelskaia rabota studentov kak vazhneishii faktor povysheniia reitinga universiteta [Research work of students as the most important factor in increasing the ranking of the university]. research.mifp.ru. Retrieved from http://www.research.mifp.ru/publications/npsh2.rtf [in Russian].

9 Somien, J. (1976). Kodirovanie sensornoi informatsii [Sensory information encoding]. Moscow: Mir [in Russian].

10 Polyakov, A.D., \& Zaitsev, G.I. (2008). Samostoiatelnaia rabota studentov — tvorchestvo prepodavatelia [Independent work of students - creativity of the teacher]. Uspekhi sovremennogo estestvoznaniia - Successes of modern natural science, 4, 51-53 [in Russian]. 